\title{
Diel vertical distribution of larvae and juveniles of pelagic and mesopelagic fishes by a newly developed frame trawl in the Kroshio-Oyashio Transition Area in spring
}

\author{
HIROSHI KUBOTA, ${ }^{1 *}$ AKIYO TSUCHYYAMA, ${ }^{2}$ YOSHIOKI OOZEKI, ${ }^{1}$ RYO KIMURA, ${ }^{1}$ RYUSUKE KADO,${ }^{2}$ HISAO OGAWA, ${ }^{2}$ \\ HUFUXIANG, ${ }^{3}$ AND KOMATSUDA ${ }^{3}$ \\ ${ }^{1}$ National Reseanch Institute of Fisheries Science, Kanazawa, Yokohama 236-8648, Japan (miles@affrc.go.jp), ${ }^{2}$ Kitasato \\ University, Sanriku, Iwate 022-0101, Japan, and ${ }^{3}$ Tokyo University of Fisheries, Minato, Tokyo 108-8477, Japan
}

KEY WORDS: diel vertical distribution, Japanese anchovy, mackerels, Jack mackerel, mesopelagic fish, frame trawl

\section{INTRODUCTION}

Stock abundance of pelagic fishes around Japan, such as Sardinops melanostictus, Engraulis japonicus and Scomber japonicus have fluctuated drastically, associated with the dynamics of young of the year (YOY). The fluctuations of mortality after the post-larval stage are important as a determinant of the YOY abundance. For the assessment of the geographical distribution, abundance, mortality and physical drift of fish in the larval and juvenile stages, it is necessary to use appropriate sampling gears for the fish size coupled with knowledge of their vertical distribution. The Kuroshio-Oyashio Transition Area is considered to be an important nursery area for pelagic fishes ${ }^{1)}$. Limitation of food due to the abundant competitors will have an impact on the growth and mortality of larvae and juveniles of pelagic fishes, and the competition will be a possible determinant of their YOY abundances.

In this paper, we used a newly developed frame trawl and clarified the diel vertical distribution of late larvae and juveniles of abundant pelagic fishes (E. japonicus and Scomber spp.) which have not been previously fully reported owing to the low catch efficiency of sampling gears, and also describe the vertical distribution of some abundant mesopelagic fishes as potential competitors.

\section{MATERIALS AND METHODS}

Samples were collected during the cruise of RV Soyo-maru (Natl. Res. Inst. Fish. Sci.) at four stations in the KuroshioOyashio Transition Area from 13 to 31 May 2000 (Fig. 1). Pre-samplings were carried out to find dense patches of late larvae of pelagic fishes by oblique tows using a frame trawl at the warm water near the thermal front found using NOAA-AVHRR images and vertical profiles of the temperature measured by XBTs. One or three floating GPS buoys each with a cylindrical drogue (diameter $1.6 \mathrm{~m}$, height $5 \mathrm{~m}$ ) at $1 \mathrm{~m}$ or $30 \mathrm{~m}$ were set to track the water mass where dense larval patches were found. All samples were collected within $4 \mathrm{~km}$ from the floating buoys. Each set consisted of four horizontal tows by the newly developed frame trawl ${ }^{2)}$ (mouth opening $5 \mathrm{~m}^{2}, 1.59 \mathrm{~mm}$ mesh, towed at $4 \mathrm{kt})$ for target layers $(1-30 \mathrm{~m}, 30-50 \mathrm{~m}, 50-70 \mathrm{~m}, 70-90 \mathrm{~m})$, and a surface tow by a neuston net ${ }^{3}$ (mouth opening $0.975 \mathrm{~m}^{2}, 0.45 \mathrm{~mm}$ mesh, towed at $4 \mathrm{kt}$ ) both day and night, and finished within 24hrs (Fig. 1). All layers except for surface were sampled horizontally with four steps in the target layer. Temperature and salinity were measured with CTD 2-7 hours before each set. Samples were fixed in $10 \%$ buffered formalin. All fish were sorted, classified at least to the order, and counted. Standard lengths (SLs) of all or a minimum of 200 anchovy and mackerels in each tow were measured to the nearest $0.1 \mathrm{~mm}$.

\section{RESULTS AND DISCUSSION}

At all stations, the thickness of the surface mixed layer was 10 to $20 \mathrm{~m}$, and the pycnocline was observed under the mixed layers to $30-40 \mathrm{~m}$ depths.

Mean filtered volume per tow was $15,005 \pm 2120 \mathrm{~m}^{3}$ for the frame trawl and $688 \pm 209 \mathrm{~m}^{3}$ for the neuston net. Deployments of the frame trawl were stable except for unusual clogging, and the differences between target and actually towed depth was less than $9 \mathrm{~m}$ at most.

A total of 248,353 fish were collected, and identified as 73 families, 110 genera and 119 species. The five most abundant species were E. japonicus (87.0\% of total), Diaphus spp. (2.9\%, Myctophidae), Myctophum asperum (2.9\%, Myctophidae), Scomber spp. (0.9\%) and Ceratoscopelus warmingii ( $0.6 \%$, Myctophidae).

$E$. japonicus less than $10 \mathrm{~mm}$ distributed in the upper $50 \mathrm{~m}$ layer at daytime, and distributed intensively at the surface at night (Fig. 2). Larvae of 10-20mm occurred in largest numbers in the $10-40 \mathrm{~m}$ layers both day and night. Larvae of $20-30 \mathrm{~mm}$ mainly occurred at $10-30 \mathrm{~m}$ layer at night, while at daytime, distributed in $10-50 \mathrm{~m}$ layers at St. 1 and 4, and often occurred in largest number at the surface (St. 1, 2 and 3). Scomber spp. less than $10 \mathrm{~mm}$ distributed 


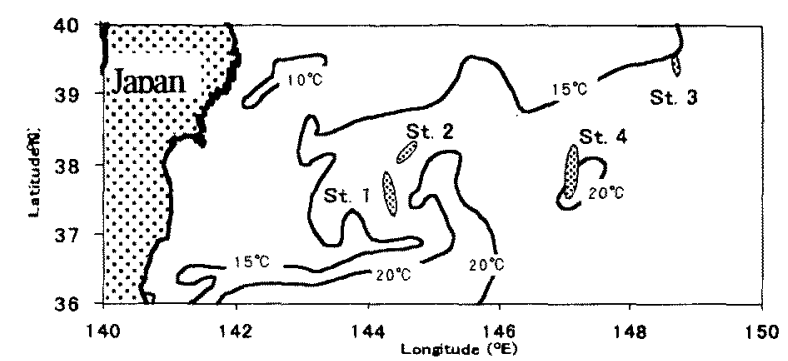

Fig. 1 Location of Stations. Sea Surface Temperature was cited from the Quick Report of Oceanography and Fishery of Pacific Ocean (from 17 to 23, May, 2001), published by Japan Fisheries Information Service Center.

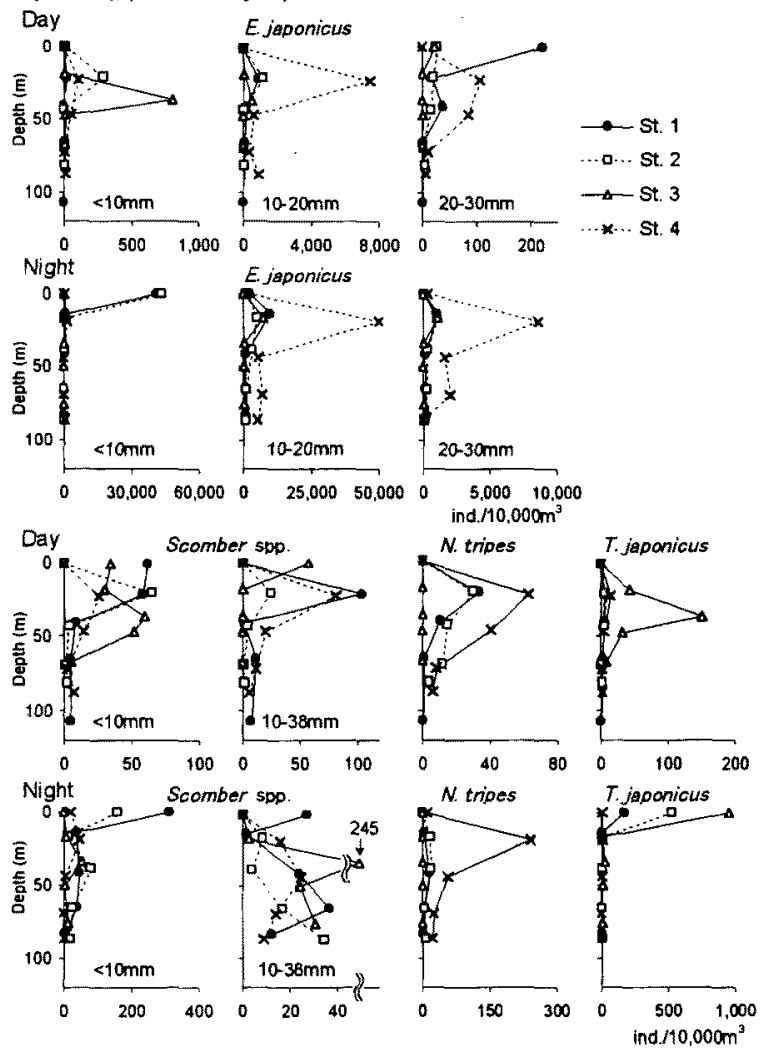

Fig. 2 Diel vertical distributions of larvae and juveniles of dominant pelagic fishes. Symbols indicate densities of each species and medians of the actually towed depth

at upper $70 \mathrm{~m}$ layer and was most abundant at $30-50 \mathrm{~m}$ at daytime, and concentrated at surface at night (Fig. 2). Scomber spp. more than $10 \mathrm{~mm}$ mainly distributed in the mixed layer and pycnocline at daytime, while occurring in and below the pycnocline (30-90m layers) at night. Average of SL was significantly larger in the lower layers by U-test $(\mathrm{p}<0.05)$ at St. 1,2 and 4 at night (ex. SL were $7.2 \pm 2.2-9.3 \pm 12.6 \mathrm{~mm}$ at $10-30 \mathrm{~m}$ layer and $11.2 \pm 6.1$ $13.8+23.1 \mathrm{~mm}$ at $70-90 \mathrm{~m})$.

Nealotus tripes, which was one of the abundant pelagic larvae and juveniles, principally distributed within the upper $50 \mathrm{~m}$ layer both day and night (Fig. 2). Trachurus japonicus and Nomeidae spp. distributed under the surface layer at daytime, and concentrated at the surface at night (Fig. 2). Juveniles of the 5 most abundant mesopelagic fishes distributed in the upper $90 \mathrm{~m}$ only at night, whereas
Table 1 Density of larvae and juveniles of dominant mesopelagic fishes in the water column from surface to the maximum towed depth (76-131m)

\begin{tabular}{|c|c|c|c|c|c|}
\hline \multirow[b]{3}{*}{ Family } & \multirow{3}{*}{$\begin{array}{l}\text { Larvae } \\
\text { Juveniles }\end{array}$} & \multicolumn{4}{|c|}{ Density (ind $/ 100 \mathrm{~m}^{2}$ ) } \\
\hline & & day & & night & \\
\hline & & es range & average & range & ver. \\
\hline Microstomatidae & $\bar{e}$ & 0.2 .6 & 1.2 & $0.3-8.6$ & $\overline{3.4}$ \\
\hline Gonostomatidae & $L$ & $0.8-16.4$ & 8.3 & $0-44.4$ & 26.3 \\
\hline & $\mathcal{L}$ & $0-1.0$ & 0.4 & $0.1-9.8$ & 3.7 \\
\hline Myc & L 1 & $155.9-221.2$ & 191.0 & $125.8-310.4$ & 224.2 \\
\hline Notosudidae & $L$ & $0-24.8$ & 7.0 & $9.2-88.7$ & 52.0 \\
\hline Microstomatidae & $J$ & & 0 & $0 \cdot 6-23.8$ & 6.7 \\
\hline & $J$ & 0.3 & 0.1 & $1.7-30.5$ & 14.6 \\
\hline Phos & 3 & $0-0.1$ & 0.03 & $4.2-134.3$ & 43.4 \\
\hline Myctophidae & $J$ & $0-1.8$ & 0.9 & $309.6-483.9$ & 406.1 \\
\hline Notosudidae & $\mathrm{J}$ & & 0 & 0.8 .6 & 2.7 \\
\hline
\end{tabular}

larvae of them were caught $13-66 \%$ of the night even during the day (Table 1). Mesopelagic fishes were principally abundant under the pycnocline, but Myctophidae and Phosichthyidae (Vinciguerria nimbaria was more than $99 \%$ ) often distributed in and above the pycnocline.

We could successfully collect late larvae of $E$. japonicus and early juveniles of Scomber spp. using the newly developed frame trawl, and described their diel vertical distributions. To evaluate quantitatively the abundance of larvae and juveniles of pelagic fishes in the $\mathrm{Ku}-$ roshio-Oyashio Transition Area, it is sufficient to sample upper $50 \mathrm{~m}$ layer for $E$ japonicus both day and night and for Scomber spp. at daytime, but at night not sufficient for Scomber spp. since it is often distributed under the pycnocline to $90 \mathrm{~m}$ layers especially larger individuals. In the case of $T$. japonicus, it will be most efficient to sample surface by a neuston net at night. Considerable competition for food was assumed among Mictophidae, $V$. nimbaria and pelagic fishes, and the predation on $E$. japonicus by Scomber spp. and $N$. tripes was also expected considering their feeding habits ${ }^{4,5)}$, since their modes of vertical distribution were often observed simultaneously in the surface mixed layer or pycnocline.

\section{REFERENCES}

1. Kubota $\mathrm{H}$, Oozeki $\mathrm{Y}$, Kimura R. Horizontal distribution of larvae and juveniles of small pelagic fishes collected by a MIKT at the northem edge of warmer water in the Kuroshio-Oyashio Transition Area in spring. Bull. Natl. Res. Inst. Fish. Sci. 2001; 16: 57-73.

2. Hu F, Oozeki Y, Tokai T, Matsuda $\mathrm{K}$ Scale model of a new midwater trawl system for sampling pelagic larval and juvenile fish Fish. Sci. 2001; 67: 254-259.

3. Oozeki Y, Kimura R, Kubota H, Ishida M. Modified neuston net for collecting larvae and juveniles of Pacific saury, Cololabis saira. Bull. Jpn. Fish. Oceanogr. 2001; 65: 1-5.

4. Grave $\mathrm{H}$ Food and feeding of mackerel larvae and early juveniles in the North Sea Rapp. P.-v. Reum. Cons. Int Explor. Mer. 1981; 178: 454-459.

5. Matsuzaki K, Ozawa T. Development of feeding-related morphologies and feeding ecology of larvae of Nealotus tripes (Gempylidae, Scombroidei). Japan. J. Ichthyol. 1998; 45: $77-85$. 